\title{
Layered double hydroxides with larger interlayer distance for enhanced pseudocapacitance
}

\author{
Yuanhua Xiao ${ }^{1}$, Dangcheng $\mathrm{Su}^{1}$, Xuezhao Wang ${ }^{1}$, Shide $\mathrm{Wu}^{1}$, Liming Zhou ${ }^{1}$, Shaoming Fang ${ }^{{ }^{*}}$ and \\ Feng $\mathrm{Li}^{2^{*}}$
}

\begin{abstract}
The interlayer space of the layered materials is not always the electrochemical active area for contributing to the pseudocapacitive process. To our knowledge, few efforts have been devoted to investigating the effect of interlayer distance of layered double hydroxides (LDHs) on pseudocapacitors. Here, we obtained the CoAl-LDH with different interlayer distance via the reaction in aqueous media hydrothermally. Electrochemical characterization reveals that the $\mathrm{CoAl}\left(\mathrm{DS}^{-}\right.$(dodecyl sulfate))-LDHs with an interlayer distance of $2.58 \mathrm{~nm}$ can deliver higher specific capacitance of 1481.7 $\mathrm{F} \mathrm{g}^{-1}$ than $\mathrm{CoAl}\left(\mathrm{SO}_{4}^{2-}\right)-\mathrm{LDH}\left(0.87 \mathrm{~nm}, 1252.7 \mathrm{~F} \mathrm{~g}^{-1}\right)$ and CoAl $\left(\mathrm{CO}_{3}^{2-}\right)-\mathrm{LDH}\left(0.76 \mathrm{~nm}, 1149.2 \mathrm{~F} \mathrm{~g}^{-1}\right)$ at a discharge current density of $1 \mathrm{~A} \mathrm{~g}^{-1}$. An asymmetric supercapacitor with the CoAl(DS ${ }^{-}$)-LDHs ||activated carbon also shows a better electrochemical performance, including a high energy density of $54.2 \mathrm{~W} \mathrm{~h} \mathrm{~kg}^{-1}$ at a power density of $0.9 \mathrm{~kW} \mathrm{~kg}^{-1}$ and a longterm stability, in comparison with $\mathrm{CoAl}\left(\mathrm{SO}_{4}^{2-}\right)-\mathrm{LDH}$ and $\mathrm{CoAl}$ $\left(\mathrm{CO}_{3}^{2-}\right)-\mathrm{LDH} \|$ activated carbon.
\end{abstract}

Keywords: layered double hydroxides, interlayer distance, hydrothermal, asymmetric supercapacitors

\section{INTRODUCTION}

To meet ever-growing demand for electrochemical energy storage, there is an urgent need in finding out a new electrochemical energy storage device as the secondary battery often suffers from low power density and poor cycle life $[1,2]$. Electrochemical capacitors (ECs), as a new storage device can provide fast charge/discharge rate, high stability and high power density, which are widely considered as a potential substitute for secondary battery in some areas and have been attracting increasing attention in recent years [3-5]. Among different types of ECs, pseudocapacitive transition metal-based oxides or hydroxides own a higher specific capacitance than carbonbased electric double-layer capacitors and a better stability than organic conducting polymer-based capacitors [6]. From a fundamental point of view, electrochemical energy storage of pseudocapacitive transition metal-based oxides or hydroxides is based mainly on the fast reversible multi-electron redox Faradaic reactions taking place on the surface of materials [1]. Thus, increasing the surface area of materials is essential for further improving their electrochemical performance. The ordered mesoporous structures with an ultrahigh surface area and the layered crystalline structures with an interlayer gap intercalated by ions can significantly enhance the accessible specific surface area $[7,8]$. However, ordered mesoporous structures have been considerably difficult to realize due to the using of hard or soft templates. And the layered crystalline structures with intercalation of ions only often occur in $\mathrm{Li}^{+}$and a high-voltage nonaqueous electrolyte system [7]. In the alkaline and acid aqueous electrolyte system, the electrolyte ion is difficult to insert into an interlayer gap of layered materials because its space is usually less than one nanometer [9]. Much effort has been devoted to stripping the layered structured materials for improving pseudocapacitive performance [10].

Apart from the hard stripping work of layered structured materials, one effective approach has recently been reported to enhance the alkali metal ion batteries capacity and to enlarge the interlayer distance, which can relax the strain and lower the barrier for metal ion intercalation and diffusion [11]. Table S1 summarizes some of the results of the layered materials with tunable interlayer distance as an electrochemical energy storage materials.

\footnotetext{
${ }^{1}$ Key Laboratory of Surface and Interface Science and Technology, Zhengzhou University of Light Industry, Zhengzhou 450002, China

${ }^{2}$ Shenyang National Laboratory for Materials Science, the Institute of Metal Research, Chinese Academy of Sciences, Shenyang 110016, China

* Corresponding authors (emails: mingfang@zzuli.edu.cn (Fang S); fli@imr.ac.cn (Li F))
} 
Therefore, the interlayer expansion is also a useful strategy to enhance the specific capacitance and rate performance of the layered materials.

Metallic layered double hydroxides (LDHs) as a typical layered material in the class of $2 \mathrm{D}$ hydrotalcite-like structure anionic clays, including CoAl-LDH [12], NiAlLDH [13] NiMn-LDH [14] and CoNi-LDH [15,16] and so on, which interlayer space can be easily adjusted by intercalation of other molecules.

In this work, we use the CoAl-LDH as the model material to investigate the effect of CoAl-LDH with different interlayer distance on electrochemical performance. The typical $\mathrm{SO}_{4}^{2-}$ and sodium dodecyl sulfate (SDS) molecules can be intercalated into the interlayer of CoAl-LDH for increasing the interlayer distance from $0.76,0.87$ to $2.58 \mathrm{~nm}$. The results of electrochemical measurements show that $\mathrm{CoAl}\left(\mathrm{DS}^{-}\right)-\mathrm{LDHs}$ with $2.58 \mathrm{~nm}$ interlayer spacing can deliver a higher specific capacitance of $1481.7 \mathrm{~F} \mathrm{~g}^{-1}$ than $\mathrm{CoAl}\left(\mathrm{SO}_{4}^{2-}\right)-\mathrm{LDHs}(0.87 \mathrm{~nm}$, $\left.1252.7 \mathrm{~F} \mathrm{~g}^{-1}\right)$ and $\mathrm{CoAl}\left(\mathrm{CO}_{3}^{2-}\right)-\mathrm{LDHs}(0.76 \mathrm{~nm}, 1149.2$ $\left.\mathrm{Fg}^{-1}\right)$ at $1 \mathrm{~A} \mathrm{~g}^{-1}$. Furthermore, an asymmetric supercapacitor (ASC) with CoAl-LDHs as positive electrode and activated carbon (AC) as negative electrode in $2 \mathrm{~mol} \mathrm{~L}^{-1} \mathrm{KOH}$ electrolyte demonstrated the $\mathrm{CoAl}\left(\mathrm{DS}^{-}\right)$LDHs ||AC possessed an ultrahigh energy density of 54.2 $\mathrm{W} \mathrm{h} \mathrm{kg}$ at a power density of $0.9 \mathrm{~kW} \mathrm{~kg}^{-1}$ and a high power density of $26.8 \mathrm{~kW} \mathrm{~kg}^{-1}$ at $29.8 \mathrm{~W} \mathrm{~h} \mathrm{~kg}^{-1}$, as well as long-term stability, outperforming $\mathrm{CoAl}\left(\mathrm{SO}_{4}^{2-}\right)-\mathrm{LDHs} \|$ $\mathrm{AC}$ and $\mathrm{CoAl}\left(\mathrm{CO}_{3}^{2-}\right)-\mathrm{LDHs} \| \mathrm{AC}$ ASCs. Our results suggest increasing the interlayer distance of $\mathrm{LDHs}$ material is an effective route for achieving high-performance supercapacitor electrode materials.

\section{EXPERIMENTAL SECTION}

\section{Synthesis of CoAl-LDHs}

CoAl(DS ${ }^{-}$-LDHs: in a typical synthesis, $1 \mathrm{mmol}$ of Co $\left(\mathrm{NO}_{3}\right)_{2} \cdot 6 \mathrm{H}_{2} \mathrm{O}, 0.5 \mathrm{mmol} \mathrm{AlCl}_{3} \cdot 6 \mathrm{H}_{2} \mathrm{O}, 5 \mathrm{mmol}$ hexamethylenetetramine (HMTA) and $4 \mathrm{mmol}$ sodium dodecyl sulfate (SDS) were dissolved into $40 \mathrm{~mL}$ of deionized water in a three-neck flask of $1000 \mathrm{~mL}$ with a magnetic stirring under bubbling nitrogen to minimize dissolved carbonate. After $5 \mathrm{~h}$, the above solution was then transferred to a $50 \mathrm{~mL}$ Teflon-lined autoclave and heated for $10 \mathrm{~h}$ at $100^{\circ} \mathrm{C}$. After the autoclave was cooled down to room temperature, the precipitates were collected by washed and dried at $60^{\circ} \mathrm{C}$.

$\mathrm{CoAl}\left(\mathrm{SO}_{4}^{2-}\right)-\mathrm{LDH}$ sere prepared by replacing the SDS with $\mathrm{Na}_{2} \mathrm{SO}_{4}$ while keeping an other reaction parameters unchanged.
$\mathrm{CoAl}\left(\mathrm{CO}_{3}^{2-}\right)-\mathrm{LDH}$ s were prepared by a method similar to the above, but without adding $\mathrm{SDS}$ or $\mathrm{Na}_{2} \mathrm{SO}_{4}$.

\section{Characterizations}

The products were characterized using X-ray diffraction (XRD, Bruker AXS D8 Advance), transmission electron microscopy (TEM, JEM-2100), Fourier transform infrared spectra (FT-IR, Nicolet 380) and X-ray photoelectron spectroscopy (XPS, ESCALAB $250 \mathrm{Xi}$ ). Thermogravimetry analysis (TGA) was performed on a thermal analyzer (SDTQ600) under nitrogen at a heating rate of $5^{\circ} \mathrm{C} \min ^{-1}$. The BET surface was measured using an apparatus (Bel Japan Inc).

\section{Electrochemical measurements}

To fabricate electrode, a mixture consisting of active materials (80 wt.\%), conductive materials (acetylene black, ATB, 10 wt.\%) and binder (polytetrafluoroethylene, PTFE, 10 wt.\%), which was coated onto a porous nickel foam sheet, and then dried at $80^{\circ} \mathrm{C}$ for $12 \mathrm{~h}$. The electrochemical measurements of individual electrodes were carried out in $2 \mathrm{~mol} \mathrm{~L}^{-1} \mathrm{KOH}$ in a three-electrode system, in which active materials, a platinum foil and an $\mathrm{Ag} / \mathrm{AgCl}$ electrode were used as working, counter and reference electrodes, respectively. The ASCs have a two-electrode system which is composed of CoAl-LDHs as the positive electrode and AC as the negative electrode. In ASC system, the mass balanced electrodes are based on the principle of the charges stored at positive electrode and negative electrode is equivalent (see the Supplementary information for the detail method) [17,18]. Electrochemical measurements of cyclic voltammogram (CV) and electrochemical impedance spectroscopy (EIS) were conducted using a $\mathrm{CHI} 660 \mathrm{E}$ electrochemical workstation. Galvanostatic charge-discharge cycle tests were performed on a CT2001A LAND test system.

The specific capacitance, energy density, and power density of the supercapacitors can be investigated from the charge/discharge test as well as in the following equation [19]:

$$
\begin{gathered}
C_{m}=\frac{2 \times i_{m} \int U \mathrm{~d} t}{\left.U^{2}\right|_{U_{\mathrm{i}}} ^{U_{\mathrm{f}}}}, \\
E=\frac{i_{m} \int U \mathrm{~d} t}{3.6}, \\
P=\frac{3600 \times E}{t},
\end{gathered}
$$

where $C_{m}$ is the specific capacitance of the supercapacitor 

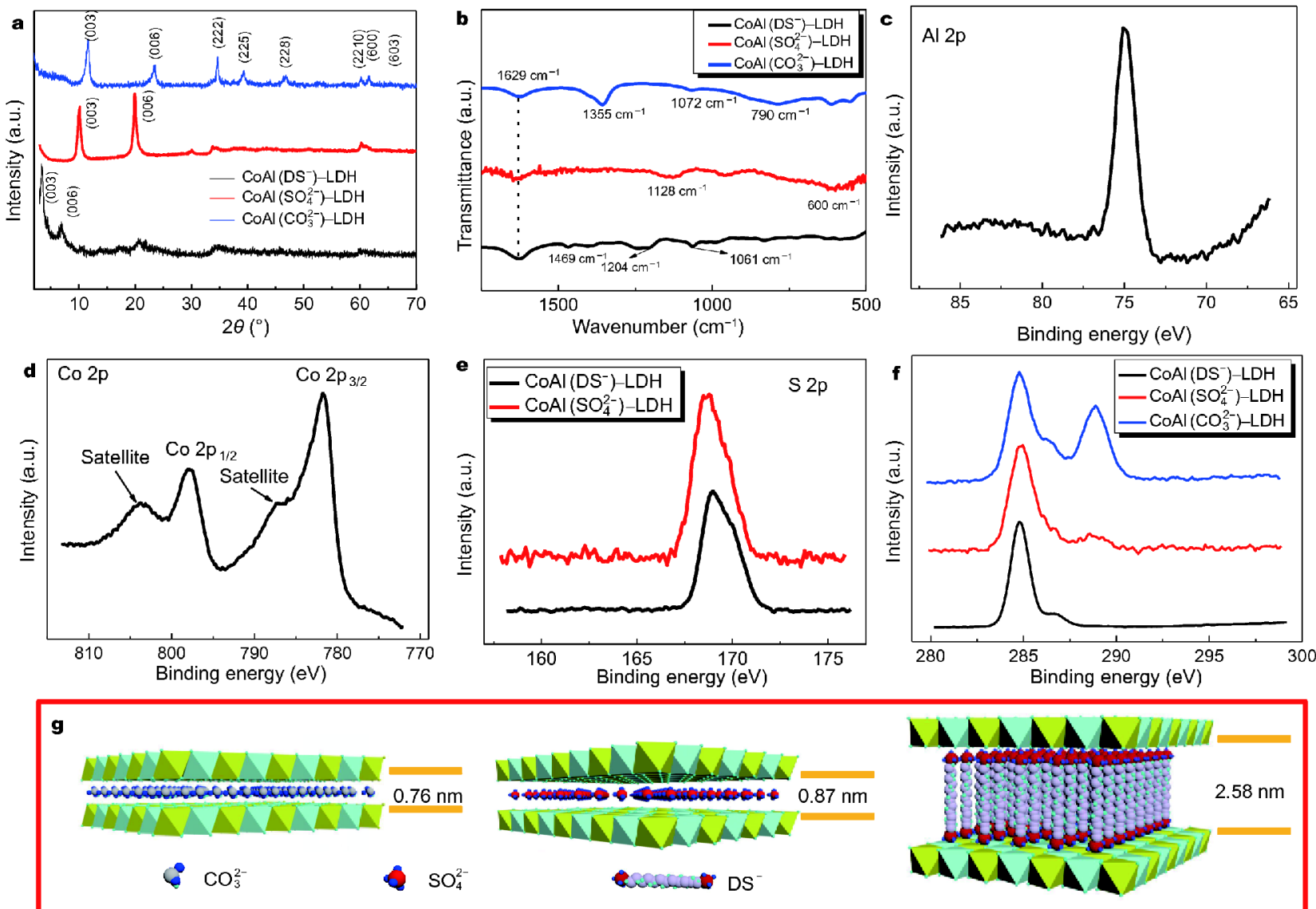

Figure 1 (a) XRD patterns and (b) FT-IR spectra of $\mathrm{CoAl}\left(\mathrm{DS}^{-}\right)-\mathrm{LDH}, \mathrm{CoAl}\left(\mathrm{SO}_{4}^{2-}\right)-\mathrm{LDH}$ and $\mathrm{CoAl}\left(\mathrm{CO}_{3}^{2-}\right)-\mathrm{LDH}$; XPS patterns of $\mathrm{Al} 2 \mathrm{p}(\mathrm{c})$ and $\mathrm{Co} 2 \mathrm{p}$ (d) for $\mathrm{CoAl}\left(\mathrm{DS}^{-}\right)-\mathrm{LDH}$, and (e) S $2 \mathrm{p}$ spectra for $\mathrm{CoAl}\left(\mathrm{DS}^{-}\right)-\mathrm{LDH}$ and $\mathrm{CoAl}\left(\mathrm{SO}_{4}^{2-}\right)-\mathrm{LDH}$; (f) XPS patterns of C 1s for $\mathrm{CoAl}\left(\mathrm{DS}^{-}\right)-\mathrm{LDH}$ and $\mathrm{CoAl}$ $\left(\mathrm{CO}_{3}^{2-}\right)-\mathrm{LDH}$. (g) Schematic illustration of the layered $\mathrm{CoAl}\left(\mathrm{CO}_{3}^{2-}\right)-\mathrm{LDH}, \mathrm{CoAl}\left(\mathrm{SO}_{4}^{2-}\right)-\mathrm{LDH}$ and $\mathrm{CoAl}\left(\mathrm{DS}^{-}\right)-\mathrm{LDH}$.

$\left(\mathrm{F} \mathrm{g}^{-1}\right), I_{m}$ is the specific current of the charge-discharge $\left(\mathrm{A} \mathrm{g}^{-1}\right), \int U \mathrm{~d} t$ is the integral current area; $U$ is the potential (V) with initial and final values of $U_{\mathrm{i}}$ and $U_{\mathrm{f}}$, respectively; $P$ is the power density $\left(\mathrm{W} \mathrm{kg}^{-1}\right) ; E$ is the energy density $\left(\mathrm{W} \mathrm{h} \mathrm{kg}^{-1}\right)$; and $t$ is the discharge time (s). In the ASC, $m$ is the total mass of active materials.

\section{RESULTS AND DISCUSSION}

Fig. 1 shows XRD pattern of as-prepared $\mathrm{CoAl}\left(\mathrm{CO}_{3}^{2-}\right)-$ $\mathrm{LDH}, \mathrm{CoAl}\left(\mathrm{SO}_{4}^{2-}\right)-\mathrm{LDH}$ and $\mathrm{CoAl}\left(\mathrm{DS}^{-}\right)-\mathrm{LDH}$. There is an important difference between three LDHs shown in peak positions of XRD. The $\mathrm{CoAl}\left(\mathrm{CO}_{3}^{2-}\right)-\mathrm{LDH}$ revealed a typical layered LDH structure and had a certain degree of similarities with those reported previously [20]. Since our synthetic $\mathrm{LDH}$ with a $\mathrm{Co} / \mathrm{Al}=2$, all the main peaks of the $\mathrm{CoAl}\left(\mathrm{CO}_{3}^{2-}\right)-\mathrm{LDH}$ sample are well corresponding to hexagonal phase $\mathrm{Mg}_{4} \mathrm{Al}_{2}(\mathrm{OH})_{12} \mathrm{CO}_{3} \cdot 3 \mathrm{H}_{2} \mathrm{O}$ (JCPDS 51-1525, a typical layered structure of LDH with hexagonal stacking) and the calculated $\left(d_{003}\right)$ basal spacing of $0.76 \mathrm{~nm}$ demonstrate that the interlayer anions should be $\mathrm{CO}_{3}^{2-}$ and water molecules [21]. The XRD patterns of $\mathrm{CoAl}\left(\mathrm{DS}^{-}\right)-\mathrm{LDH}$ and $\mathrm{CoAl}\left(\mathrm{SO}_{4}^{2-}\right)-\mathrm{LDH}$ show the main peak of (003) moving from $2 \theta$ of $11.2^{\circ}, 10.1^{\circ}$ to $2.1^{\circ}$, which is corresponding to the basal spacing increasing from $2 \theta$ of $0.76 \mathrm{~nm}, 0.87 \mathrm{~nm}$ to $2.58 \mathrm{~nm}$, respectively. The significant increasing of LDH interlamellar distance was caused mainly by the intercalation of $\mathrm{SO}_{4}^{2-}$ and $\mathrm{DS}^{-}$molecule into the interlayer spaces. In addition, the longchain $\mathrm{DS}^{-}$molecules likely form a perpendicular monolayer in the LDH interlamellar spaces [22,23]. The corresponding schematic diagrams of $\mathrm{CoAl}\left(\mathrm{CO}_{3}^{2-}\right)-\mathrm{LDH}$, $\mathrm{CoAl}\left(\mathrm{SO}_{4}^{2-}\right)-\mathrm{LDH}$ and $\mathrm{CoAl}\left(\mathrm{DS}^{-}\right)-\mathrm{LDH}$ were presented in Fig. 1g.

FT-IR analysis was used to confirm the existence of different interlayer anions, as shown in Fig. 1b. The peaks centered at $1629 \mathrm{~cm}^{-1}$ correspond to the bending vibra- 

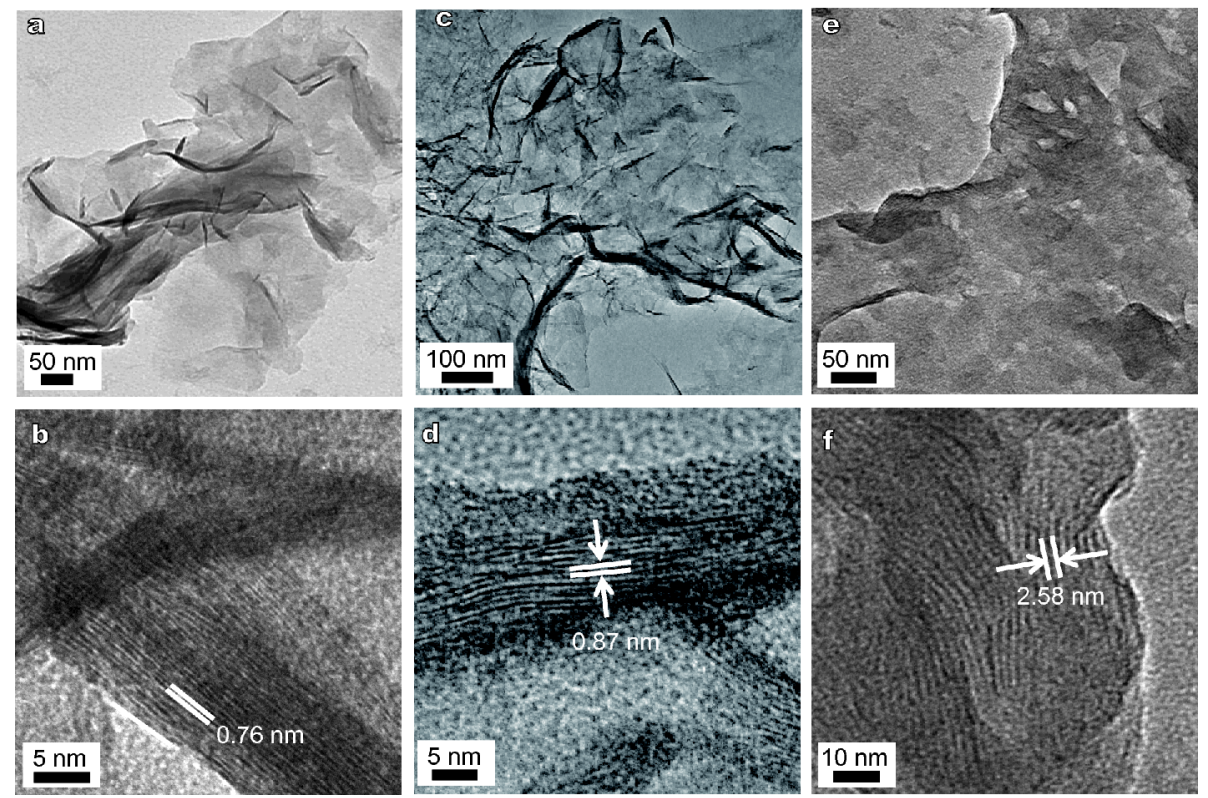

Figure 2 TEM and HRTEM images of the as-obtained (a-b) $\mathrm{CoAl}\left(\mathrm{CO}_{3}^{2-}\right)-\mathrm{LDH},(\mathrm{c}-\mathrm{d}) \mathrm{CoAl}\left(\mathrm{SO}_{4}^{2-}\right)-\mathrm{LDH}$ and (e-f) $\mathrm{CoAl}\left(\mathrm{DS}^{-}\right)-\mathrm{LDH}$ samples.

tions of water molecules in the interlayer or adsorbed on the surface. In the spectrum of $\operatorname{CoAl}\left(\mathrm{CO}_{3}^{2-}\right)-\mathrm{LDH}$, peaks at 1355 and $790 \mathrm{~cm}^{-1}$ are ascribed to the presence of intercalated $\mathrm{CO}_{3}^{2-}$ ion. The absorption peak of $\mathrm{CoAl}\left(\mathrm{SO}_{4}^{2-}\right)-$ $\mathrm{LDH}$ in 1128 and $600 \mathrm{~cm}^{-1}$ is attributable to the asymmetric and symmetric stretching vibration of $\mathrm{S}=\mathrm{O}$ and $\mathrm{S}-$ O bonds, respectively. As for the spectrum of $\mathrm{CoAl}\left(\mathrm{DS}^{-}\right)-$ $\mathrm{LDH}$, the peak at $1469 \mathrm{~cm}^{-1}$ are related to the bending vibrations of $-\mathrm{CH}_{2}-$ in alkyl chains of $\mathrm{DS}^{-}$, while a series of relatively weak bands in the range 1200 to $1000 \mathrm{~cm}^{-1}$ are mainly ascribed to stretching mode of sulfate $\left(\mathrm{OSO}^{3-}\right)$ [24].

To confirm the chemical compositions of the samples, we performed XPS analysis. Firstly, compositional elements of the $\mathrm{CoAl}\left(\mathrm{DS}^{-}\right)-\mathrm{LDH}, \mathrm{CoAl}\left(\mathrm{SO}_{4}^{2-}\right)-\mathrm{LDH}$ and $\mathrm{CoAl}\left(\mathrm{CO}_{3}^{2-}\right)-\mathrm{LDH}$ can be identified by the full survey scanned XPS spectra, as shown in Fig. S1a-c. Fig. 1c reveals the $\mathrm{Al} 2 \mathrm{p}$ spectra of $\mathrm{CoAl}\left(\mathrm{DS}^{-}\right)-\mathrm{LDH}$ with a peak at a binding energy of $74.9 \mathrm{eV}$, the result related to the $\mathrm{Al}^{3+}$ species in the form of $\mathrm{Al}-\mathrm{OH}$ [25]. The Co 2p spectra (Fig. 1d, $\left.\mathrm{CoAl}\left(\mathrm{DS}^{-}\right)-\mathrm{LDH}\right)$ exhibited two main peaks at $781.7 \mathrm{eV}$ and $797.7 \mathrm{eV}$ with a spin-orbit splitting of $16 \mathrm{eV}$, corresponding to Co $2 \mathrm{p}_{2 / 3}$ and Co $2 \mathrm{p}_{1 / 2}$, respectively [26]. Depending on the full-spectra (Fig. S1a-c), the $\mathrm{Al} 2 \mathrm{p}$ and Co $2 \mathrm{p}$ spectra of $\mathrm{CoAl}\left(\mathrm{DS}^{-}\right)-\mathrm{LDH}$ and $\mathrm{CoAl}$ $\left(\mathrm{SO}_{4}^{2-}\right)-\mathrm{LDH}$ are similar to that of $\mathrm{CoAl}\left(\mathrm{CO}_{3}^{2-}\right)-\mathrm{LDH}$, further indicating the $\mathrm{CoAl}\left(\mathrm{DS}^{-}\right)-\mathrm{LDH}$ and $\mathrm{CoAl}\left(\mathrm{SO}_{4}^{2-}\right)-$ LDH possess the similar composition structure. From the S 2p spectra (Fig. 1e), the apparent peaks are observed at around $168.9 \mathrm{eV}$, which can be assigned to $-\mathrm{SO}_{4}^{2-}$, confirming the presence of $\mathrm{DS}^{-}$and $\mathrm{SO}_{4}^{2-}$ in the $\mathrm{CoAl}\left(\mathrm{DS}^{-}\right)-$ $\mathrm{LDH}$ and $\mathrm{CoAl}\left(\mathrm{SO}_{4}^{2-}\right)-\mathrm{LDH}$, respectively [27]. $\mathrm{CO}_{3}^{2-}$ ions usually have the stronger Coulombic attraction with the LDH layer than other ions [28]. For comparison, all the three $\mathrm{C}$ 1s spectra of the $\mathrm{CoAl}\left(\mathrm{CO}_{3}^{2-}\right)-\mathrm{LDH}, \mathrm{CoAl}\left(\mathrm{SO}_{4}^{2-}\right)-$ $\mathrm{LDH}$ and $\mathrm{CoAl}\left(\mathrm{DS}^{-}\right)-\mathrm{LDH}$ were shown in Fig. 1f. Except that the same main peak of $284.77 \mathrm{eV}$ of the three materials is corresponding to adventitious carbon, the another main peak of $\mathrm{CoAl}\left(\mathrm{CO}_{3}^{2-}\right)-\mathrm{LDH}$ at $288.90 \mathrm{eV}$ can be attributed to carbonate ions [29]. This result also demonstrated that there was no $\mathrm{CO}_{3}^{2-}$ in the $\mathrm{CoAl}\left(\mathrm{SO}_{4}^{2-}\right)-$ LDH and $\mathrm{CoAl}\left(\mathrm{DS}^{-}\right)-\mathrm{LDHs}$.

Fig. 2 displays the typical TEM images of the CoAlLDHs from low to high magnifications. As it can be seen, the $\mathrm{CoAl}\left(\mathrm{CO}_{3}^{2-}\right)-\mathrm{LDH}, \quad \mathrm{CoAl}\left(\mathrm{SO}_{4}^{2-}\right)-\mathrm{LDH}$ and $\mathrm{CoAl}$ (DS $\left.{ }^{-}\right)-\mathrm{LDH}$ samples exhibit the irregular sheet-like shapes, as shown in Fig. 2a, c, e. From the edge folds of the sheets, HRTEM images of Fig. $2 b, d, f$ demonstrated the lattice spacing of (003) of $\mathrm{CoAl}\left(\mathrm{CO}_{3}^{2-}\right)-\mathrm{LDHs}$ increasing from $0.76,0.87$ to $2.58 \mathrm{~nm}$ after intercalation of $\mathrm{SO}_{4}^{2-}$ and $\mathrm{DS}^{-}$molecules into the interlayer spaces, which are in good agreement with the above XRD, FT-IR and XPS results.

Fig. 3 presents TGA curves of the $\mathrm{CoAl}\left(\mathrm{CO}_{3}^{2-}\right)-\mathrm{LDH}$, $\mathrm{CoAl}\left(\mathrm{SO}_{4}^{2-}\right)-\mathrm{LDH}$ and $\mathrm{CoAl}\left(\mathrm{DS}^{-}\right)-\mathrm{LDH}$. As it can be observed in Fig. 3, the first weight loss (16.4 wt.\%) for the $\mathrm{CoAl}\left(\mathrm{CO}_{3}^{2-}\right)-\mathrm{LDH}$ and (16.5 wt.\%) for $\mathrm{CoAl}\left(\mathrm{SO}_{4}^{2-}\right)-\mathrm{LDH}$ occurred at the low temperature (ca. $20-230^{\circ} \mathrm{C}$ ) is at- 
tributed to the release of surface water. The second weight loss (11.6 wt.\%) for $\mathrm{CoAl}\left(\mathrm{CO}_{3}^{2-}\right)-\mathrm{LDH}$ and (11.9 wt.\%) for $\mathrm{CoAl}\left(\mathrm{SO}_{4}^{2-}\right)-\mathrm{LDH}$ respectively occurred temperature range of $230-320^{\circ} \mathrm{C}$ and $230-420^{\circ} \mathrm{C}$, which is corresponding to removal of water intercalated in the interlayer galleries and the partial dehydroxylation of the $\mathrm{LDH}$ sheets. The third weight loss $(8.7 \mathrm{wt} . \%)$ for $\mathrm{CoAl}\left(\mathrm{CO}_{3}^{2-}\right)-$ $\mathrm{LDH}$ and (12.1 wt.\%) for $\mathrm{CoAl}\left(\mathrm{SO}_{4}^{2-}\right)-\mathrm{LDH}$ occurred at the next high temperature range can be attributed to the dehydroxylation of the layers as well as removal of volatile species $\left(\mathrm{CO}_{2}\right)$ and $\mathrm{SO}_{2}$ arising from the interlayer carbonate anions [30]. As for the $\mathrm{CoAl}\left(\mathrm{DS}^{-}\right)-\mathrm{LDH}$, the percentage of weight loss is different from the $\mathrm{CoAl}$ $\left(\mathrm{CO}_{3}^{2-}\right)-\mathrm{LDH}$ and $\mathrm{CoAl}\left(\mathrm{SO}_{4}^{2-}\right)-\mathrm{LDH}$. Undoubtedly, the first weight loss (9.5 wt.\%) below $160^{\circ} \mathrm{C}$ originated from a removal of water physically adsorbed on the external surface. The second and the main degradation step, occurred at the temperature between 180 and $500^{\circ} \mathrm{C}$, result from the removal of gallery water, dehydroxylation of the LDH sheets, as well as the partial decomposition of the intercalated $\mathrm{DS}^{-}$organic long-chain molecules. The last weight loss (13.5 wt.\%) above $500^{\circ} \mathrm{C}$ mainly corresponds to further decomposition of the intercalated $\mathrm{DS}^{-}$longchain molecules.

Electrochemical properties of synthetic LDH samples were first evaluated by CV, galvanostatic charge-dis-

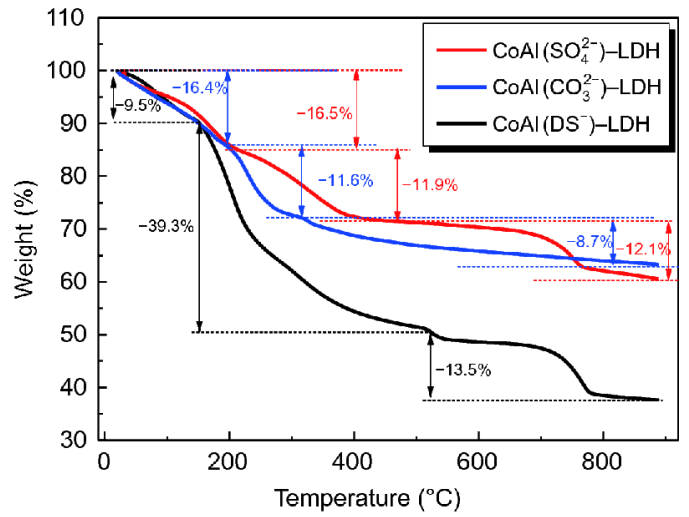

Figure $3 \mathrm{~A}$ thermogravimetric curve for $\mathrm{CoAl}\left(\mathrm{CO}_{3}^{2-}\right)-\mathrm{LDH}, \mathrm{CoAl}\left(\mathrm{SO}_{4}\right.$ $\left.{ }^{2-}\right)-\mathrm{LDH}$ and $\mathrm{CoAl}\left(\mathrm{DS}^{-}\right)-\mathrm{LDH}$.

charge and EIS measurements using three-electrode system. Fig. 4 a shows the typical CV curves of $\mathrm{CoAl}\left(\mathrm{CO}_{3}^{2-}\right)-$ $\mathrm{LDH}, \mathrm{CoAl}\left(\mathrm{SO}_{4}^{2-}\right)-\mathrm{LDH}$ and $\mathrm{CoAl}\left(\mathrm{DS}^{-}\right)-\mathrm{LDH}$ in the voltage range from 0 to $0.45 \mathrm{~V}(v s . \mathrm{Ag} / \mathrm{AgCl})$ at a scan rate of $10 \mathrm{mV} \mathrm{s}^{-1}$. Two pairs of apparent redox peaks of each curve indicate that pseudocapacitive characteristics arose from Faradaic reactions, which are as follows:

$$
\begin{gathered}
\mathrm{Co}(\mathrm{OH})_{2}+\mathrm{OH}^{-} \leftrightharpoons \mathrm{CoOOH}+\mathrm{H}_{2} \mathrm{O}+\mathrm{e}^{-}, \\
\mathrm{CoOOH}+\mathrm{OH}^{-} \leftrightharpoons \mathrm{CoO}_{2}+\mathrm{H}_{2} \mathrm{O}+\mathrm{e}^{-} .
\end{gathered}
$$

It can also be clearly seen that the order of area sur-
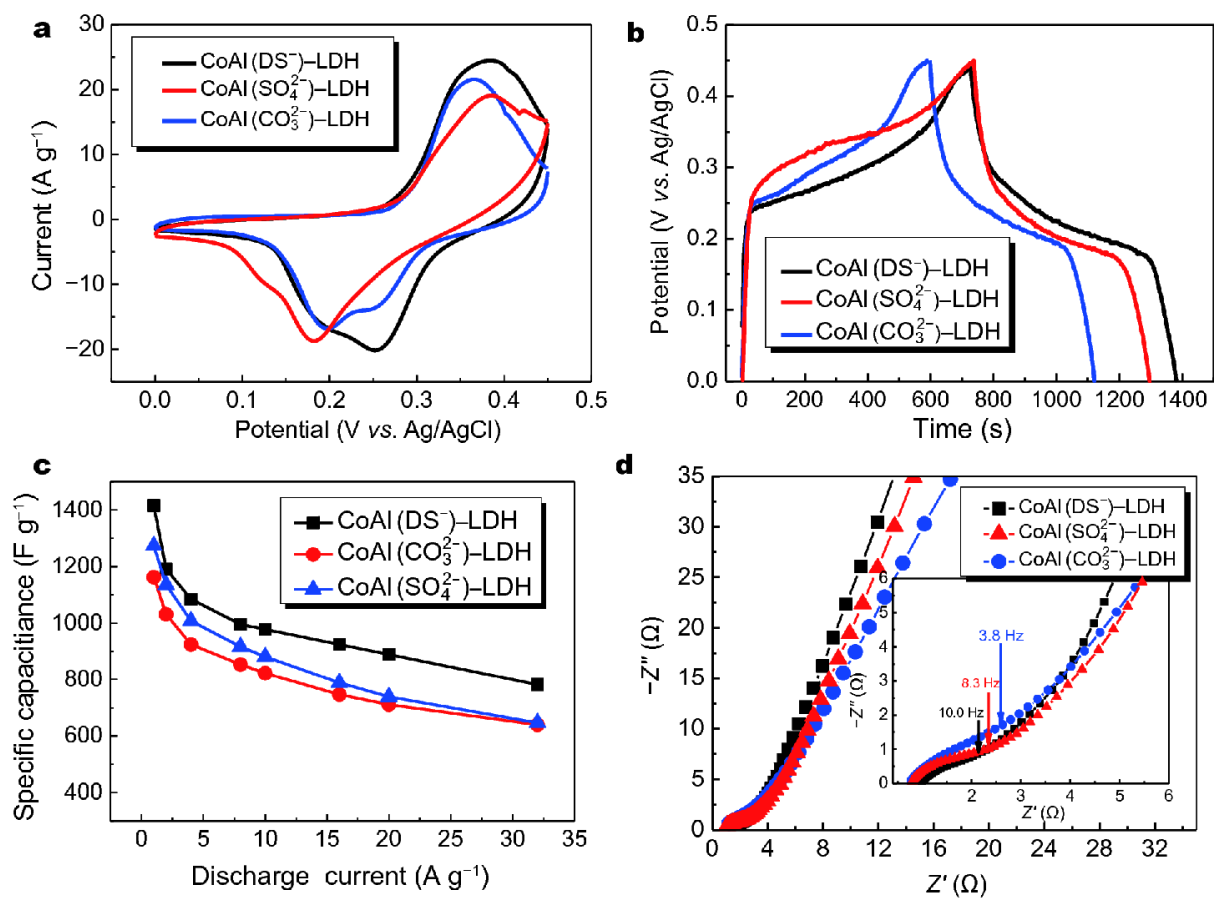

Figure 4 (a) Cyclic voltammograms, (b) galvanostatic charge-discharge curves, (c) specific capacitances at different current densities and (d) Nyquist plots of $\mathrm{CoAl}\left(\mathrm{CO}_{3}^{2-}\right)-\mathrm{LDH}, \mathrm{CoAl}\left(\mathrm{SO}_{4}^{2-}\right)-\mathrm{LDH}$ and $\mathrm{CoAl}\left(\mathrm{DS}^{-}\right)-\mathrm{LDH}$. 
rounded by the $\mathrm{CV}$ curves is $\mathrm{CoAl}\left(\mathrm{DS}^{-}\right)-\mathrm{LDH}, \mathrm{CoAl}$ $\left(\mathrm{SO}_{4}^{2-}\right)-\mathrm{LDH}$ and $\mathrm{CoAl}\left(\mathrm{DS}^{-}\right)-\mathrm{LDH}$, implying that increasing of $\mathrm{LDH}$ interlamellar distance by the intercalation of long-chain $\mathrm{DS}^{-}$or $\mathrm{SO}_{4}^{2-}$ molecule is related to enhancing the capacitive behavior of the LDH electrode. The corresponding galvanostatic charge-discharge profiles at $1 \mathrm{Ag}^{-1}$ (Fig. 4b) reveal a voltage plateau in the charge-discharge process, which is in agreement with the $\mathrm{CV}$ curves and the previous reports in the literature $[8,15]$. Additionally, significantly extended charge-discharge time of $\mathrm{CoAl}\left(\mathrm{DS}^{-}\right)-\mathrm{LDH}$ electrode indicated its improved charge storage capacity. Fig. $4 \mathrm{c}$ gives the plot of specific capacitance of $\mathrm{CoAl}\left(\mathrm{CO}_{3}^{2-}\right)-\mathrm{LDH}, \mathrm{CoAl}\left(\mathrm{SO}_{4}^{2-}\right)-$ $\mathrm{LDH}$ and $\mathrm{CoAl}\left(\mathrm{DS}^{-}\right)-\mathrm{LDH}$ that are calculated by the Eqation (1) based on the discharge curves at different current densities. The CoAl(DS $\left.{ }^{-}\right)-\mathrm{LDH}$ shows the specific capacitance is as high as 1481.7, 1228.2, 1141.5, 1070.0, 1042.1, 962.5, 942.9 and $856.7 \mathrm{~F} \mathrm{~g}^{-1}$ at discharge current densities of $1,2,4,8,10,16,20$ and $32 \mathrm{~A} \mathrm{~g}^{-1}$, respectively. This performance of $\mathrm{CoAl}\left(\mathrm{DS}^{-}\right)-\mathrm{LDH}$, at corresponding current densities, is much higher than $\mathrm{CoAl}\left(\mathrm{SO}_{4}^{2-}\right)-\mathrm{LDH}$, $\mathrm{CoAl}\left(\mathrm{CO}_{3}^{2-}\right)-\mathrm{LDH}$ supercapacitors, and even higher than some carbon-based CoAl-LDH nanocomposites, such as fluorinated graphene/CoAl-LDH $\left(1222 \mathrm{~F} \mathrm{~g}^{-1}, 1 \mathrm{~A} \mathrm{~g} \mathrm{~g}^{-1}\right.$, $0.5 \mathrm{~V})$ [31], and graphene foam/CoAl-LDH $\left(775.6 \mathrm{~F} \mathrm{~g} \mathrm{~g}^{-1}\right.$, $\left.0.5 \mathrm{~A} \mathrm{~g}^{-1}, 0.4 \mathrm{~V}\right)$ [32].

From the Nyquist plots in Fig. $4 \mathrm{~d}, \mathrm{CoAl}\left(\mathrm{CO}_{3}^{2-}\right)-\mathrm{LDH}$, $\mathrm{CoAl}\left(\mathrm{SO}_{4}^{2-}\right)-\mathrm{LDH}$ and $\mathrm{CoAl}\left(\mathrm{DS}^{-}\right)-\mathrm{LDH}$ electrodes possess almost the same charge transfer resistance, which is represented by the diameter of the semicircle in the highfrequency region. The most noteworthy difference comes from the slope in the Warburg region (low frequency), which is related to solid-state ion diffusion in bulk material. It is very clearly seen that the $\mathrm{CoAl}\left(\mathrm{DS}^{-}\right)-\mathrm{LDH}$ exhibited a steeper slope compared with $\mathrm{CoAl}\left(\mathrm{SO}_{4}^{2-}\right)-$ $\mathrm{LDH}$ and $\mathrm{CoAl}\left(\mathrm{CO}_{3}^{2-}\right)-\mathrm{LDH}$, suggesting the $\mathrm{CoAl}\left(\mathrm{DS}^{-}\right)-$ LDH electrode possessed a high ion mobility and diffusion. In addition, the higher Knee frequency $(10.0 \mathrm{~Hz})$ of $\mathrm{CoAl}\left(\mathrm{DS}^{-}\right)-\mathrm{LDH}$ electrodes than $\mathrm{CoAl}\left(\mathrm{SO}_{4}^{2-}\right)-\mathrm{LDH}$ $(8.3 \mathrm{~Hz})$ and $\mathrm{CoAl}\left(\mathrm{CO}_{3}^{2-}\right)-\mathrm{LDH}(3.8 \mathrm{~Hz})$, further demonstrates the more accessible interlayer space of $\mathrm{CoAl}$ $\left(D^{-}\right)-L D H$. Furthermore, Fig. S2 shows the frequency dependent specific capacitance values of $\mathrm{LDHs}$, calculated from impedance measurements. The appreciably higher specific capacitance values of $\mathrm{CoAl}\left(\mathrm{DS}^{-}\right)-\mathrm{LDH}$ electrodes in a wide range from low to high frequency demonstrate their high power performance and excellent rate response. The equivalent electrical circuit for the $\mathrm{R}((\mathrm{CR})$ (QW)) model simulated by the ZSimpWin programme (inset in Fig. S2) and the fitted parameters (Table S2) are in good agreement with the discussion above.

To evaluate the ASC performance of the $\mathrm{CoAl}\left(\mathrm{CO}_{3}^{2-}\right)-$ $\mathrm{LDH}, \mathrm{CoAl}\left(\mathrm{SO}_{4}^{2-}\right)-\mathrm{LDH}$ and $\mathrm{CoAl}\left(\mathrm{DS}^{-}\right)-\mathrm{LDH}$ as the positive electrode material in real cell, we select the activated carbon with an excellent electric double-layer capacitance property at -1.0 to $0.0 \mathrm{~V}$ as the negative electrode material (see Fig. S3). Fig. 5a shows typical CV curves for the $\mathrm{CoAl}\left(\mathrm{DS}^{-}\right)-\mathrm{LDH}\left\|\mathrm{AC}, \mathrm{CoAl}\left(\mathrm{SO}_{4}^{2-}\right)-\mathrm{LDH}\right\|$ $\mathrm{AC}$ and $\mathrm{CoAl}\left(\mathrm{CO}_{3}^{2-}\right)-\mathrm{LDH} \| \mathrm{AC}$ in $2 \mathrm{~mol} \mathrm{~L}^{-1} \mathrm{KOH}$ electrolyte with various scan rates at $0.0-1.7 \mathrm{~V}$. It can be easily observed that the $\mathrm{CV}$ curves of $\mathrm{CoAl}\left(\mathrm{DS}^{-}\right)-\mathrm{LDH} \|$ AC display a larger integrated area than those of CoAl $\left(\mathrm{SO}_{4}^{2-}\right)-\mathrm{LDH} \| \mathrm{AC}$ and $\mathrm{CoAl}\left(\mathrm{CO}_{3}^{2-}\right)-\mathrm{LDH} \| \mathrm{AC}$, suggesting the better capacitive behavior of $\mathrm{CoAl}\left(\mathrm{DS}^{-}\right)-\mathrm{LDH} \| \mathrm{AC}$. Fig. $5 \mathrm{~b}$ reveals the comparison of galvanostatic chargedischarge behavior for the $\mathrm{CoAl}\left(\mathrm{DS}^{-}\right)-\mathrm{LDH} \| \mathrm{AC}, \mathrm{CoAl}$ $\left(\mathrm{SO}_{4}^{2-}\right)-\mathrm{LDH} \| \mathrm{AC}$ and $\mathrm{CoAl}\left(\mathrm{CO}_{3}^{2-}\right)-\mathrm{LDH} \| \mathrm{AC}$ at $1 \mathrm{~A} \mathrm{~g}^{-1}$. As expected, because of the $\mathrm{CoAl}\left(\mathrm{DS}^{-}\right)-\mathrm{LDH}$ with a better electrochemical performance, the $\mathrm{CoAl}\left(\mathrm{DS}^{-}\right)$$\mathrm{LDH} \| \mathrm{AC}$ possess the much longer charge-discharge time, which has a specific capacitance of $137.8 \mathrm{~F} \mathrm{~g}^{-1}$ based on the total active materials superior to the $\mathrm{CoAl}\left(\mathrm{SO}_{4}^{2-}\right)$ $\mathrm{LDH} \| \mathrm{AC}$ and $\operatorname{CoAl}\left(\mathrm{CO}_{3}^{2-}\right)-\mathrm{LDH} \| \mathrm{AC}$. Fig. $5 \mathrm{c}$ also shows the specific capacitances of an asymmetric cell calculated by the Eqation (1) according to the discharge curves as the function of different discharging current densities. With increasing current density, the specific capacitances decrease gradually as the diffusion limits the movement of electrolyte ions at high current densities, because of time constraint and only the active outer surface and the bigger size of pore volume utilized for charge storage. Nevertheless, the CoAl( $\left.\mathrm{DS}^{-}\right)-\mathrm{LDH}|| \mathrm{AC}$ still maintains a good rate in its performances, such as the $\mathrm{CoAl}\left(\mathrm{DS}^{-}\right)$$\mathrm{LDH} \| \mathrm{AC}$ with a $74.2 \mathrm{~F} \mathrm{~g}^{-1}$ at a very high current density of $32 \mathrm{~A} \mathrm{~g}^{-1}$, retained $53.8 \%$ of its initial capacitance obtained in $1 \mathrm{~A} \mathrm{~g}^{-1}$, and the $\mathrm{CoAl}\left(\mathrm{SO}_{4}^{2-}\right)-\mathrm{LDH} \| \mathrm{AC}$ and $\mathrm{CoAl}\left(\mathrm{CO}_{3}^{2-}\right)-\mathrm{LDH} \| \mathrm{AC}$ respectively retained $32.0 \%$ and $28.0 \%$ of their capacitance when the charge-discharge rate increased from 1 to $32 \mathrm{~A} \mathrm{~g}^{-1}$.

Cycling stability of ASC also is the critical issue for its practical application, and the cycle charge-discharge testing was employed to examine the cycle stability. Fig. $5 \mathrm{~d}$ shows a long-term cycling performance of the CoAl $\left(\mathrm{CO}_{3}^{2-}\right)-\mathrm{LDH} \| \mathrm{AC}$ cell retaining more than $87 \%$ of initial capacitance after 5000 charge-discharge cycles at a current density of $20 \mathrm{~A} \mathrm{~g}^{-1}$, which is significantly better than the retention of $49 \%$ for $\mathrm{CoAl}\left(\mathrm{SO}_{4}^{2-}\right)-\mathrm{LDH} \| \mathrm{AC}$ and $61 \%$ for $\mathrm{CoAl}\left(\mathrm{CO}_{3}^{2-}\right)-\mathrm{LDH} \| \mathrm{AC}$ cell.

The energy and power densities of ASCs devices have been further evaluated. As showed in Fig. 6, the Ragone 

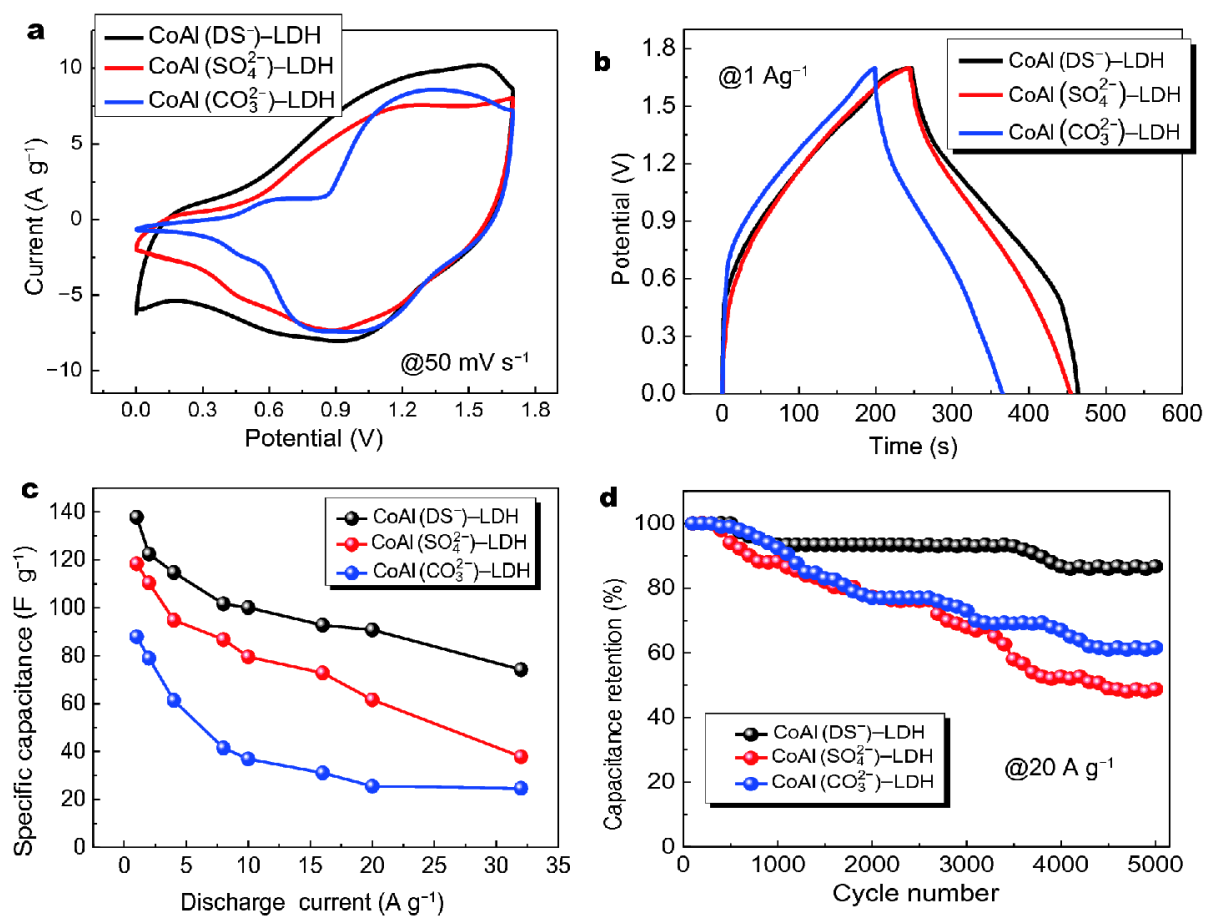

Figure 5 (a) Cyclic voltammograms at different scan rates and (b) charge-discharge curves at a current density of $1 \mathrm{~A} \mathrm{~g}^{-1}$ and corresponding specific capacitance in different cell voltages for CoAl-LDH $\mid \mathrm{AC}$ in $2 \mathrm{~mol} \mathrm{~L}^{-1} \mathrm{KOH}$ solution. Specific capacitances (c) and cycle stability $(\mathrm{d})$ of $\mathrm{CoAl}\left(\mathrm{CO}_{3}^{2-}\right)-$ $\mathrm{LDH}\left\|\mathrm{AC}, \mathrm{CoAl}\left(\mathrm{SO}_{4}^{2-}\right)-\mathrm{LDH}\right\| \mathrm{AC}$ and $\mathrm{CoAl}\left(\mathrm{DS}^{-}\right)-\mathrm{LDH} \| \mathrm{AC}$.

plot of $\mathrm{CoAl}\left(\mathrm{DS}^{-}\right)-\mathrm{LDH} \| \mathrm{AC}$ device displayed a high energy density of $54.2 \mathrm{~W} \mathrm{~h} \mathrm{~kg}^{-1}$ at a power density of $0.9 \mathrm{~kW} \mathrm{~kg}^{-1}$ and a high power density of $26.8 \mathrm{~kW} \mathrm{~kg}^{-1}$ at $29.8 \mathrm{~W} \mathrm{~h} \mathrm{~kg}^{-1}$. The performance of this $\mathrm{CoAl}\left(\mathrm{DS}^{-}\right)-\mathrm{LDH} \|$ $\mathrm{AC}$ is much higher than most of carbon based symmetrical supercapacitors (less than $10 \mathrm{~W} \mathrm{~h} \mathrm{~kg}^{-1}$ ) [33] and many of pseudocapacitor electrode materials reported recently, including metal oxide, sulfide-based and hydroxide ASCs, such as $\mathrm{NiO} \| \mathrm{GR}\left(39.9 \mathrm{~W} \mathrm{~h} \mathrm{~kg}^{-1}\right)$ [34], $\mathrm{Co}_{3} \mathrm{O}_{4} @ \mathrm{MnO}_{2} \| \mathrm{GO}\left(17.7 \mathrm{~W} \mathrm{~h} \mathrm{~kg}{ }^{-1}\right)$ [35], $\mathrm{CoS}_{x} \|$ GR (14.7 $\mathrm{W} \mathrm{h} \mathrm{kg}{ }^{-1}$ ) [36], CNT/Ni(OH) $)_{2} \| \mathrm{rGO}\left(35 \mathrm{~W} \mathrm{~h} \mathrm{~kg}^{-1}\right)$ [37], $\mathrm{Ni}-\mathrm{Mn} \mathrm{LDH} / \mathrm{rGO} \| \mathrm{AC}\left(33.8 \mathrm{~W} \mathrm{~h} \mathrm{~kg}{ }^{-1}\right)$ [38], Co-Al LDHs-CNTs $\|$ AC (28 $\mathrm{W} \mathrm{h} \mathrm{kg}^{-1}$ ) [39], GO/NiAl-LDHs\| AC (21 W h kg-1) [40], $\mathrm{Ni}_{x} \mathrm{Co}_{1-x} \mathrm{LDH}-\mathrm{ZTO} \| \mathrm{AC}(23.7$ $\left.\mathrm{W} \mathrm{h} \mathrm{kg}{ }^{-1}\right)$ [41] and $\mathrm{AC} \| \mathrm{Co}(\mathrm{OH})_{2}$ buds/Ni foam (20.3 $\left.\mathrm{W} \mathrm{h} \mathrm{kg}{ }^{-1}\right)$ [42].

In contrast, the $\mathrm{CoAl}\left(\mathrm{CO}_{3}^{2-}\right)-\mathrm{LDH} \| \mathrm{AC}$ ASC only exhibited the highest energy density of $40.8 \mathrm{~W} \mathrm{~h} \mathrm{~kg}^{-1}$ at a power density of $0.8 \mathrm{~kW} \mathrm{~kg}^{-1}$ and the highest power density of $11.8 \mathrm{~kW} \mathrm{~kg}^{-1}$ at a energy density of 9.9 $\mathrm{W} \mathrm{h} \mathrm{kg}{ }^{-1}$. The improved electrochemical performance of the $\mathrm{CoAl}\left(\mathrm{DS}^{-}\right)-\mathrm{LDH}$ might be largely attributed to its structural features. Although, the $\mathrm{CoAl}\left(\mathrm{CO}_{3}^{2-}\right)-\mathrm{LDHs}$ have a higher BET surface of $60.54 \mathrm{~m}^{2} \mathrm{~g}^{-1}$ than the CoAl

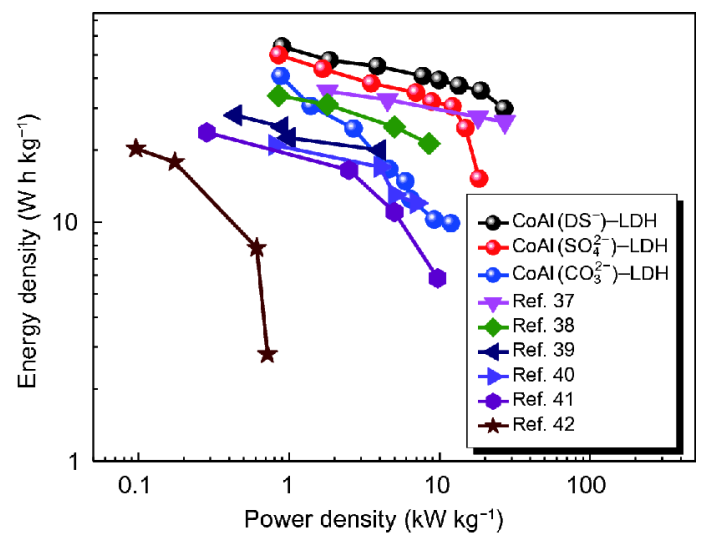

Figure 6 Ragone plots of CoAl-LDH||AC. The values reported from other $\mathrm{LDH}$ and hydroxide based ASCs are inserted for comparison.

(DS $)-\mathrm{LDH}\left(58.36 \mathrm{~m}^{2} \mathrm{~g}^{-1}\right)$ and $\mathrm{CoAl}\left(\mathrm{SO}_{4}^{2-}\right)-\mathrm{LDH}(41.50$ $\mathrm{m}^{2} \mathrm{~g}^{-1}$ ) (Fig. S4). The larger interlayer spacing of $\mathrm{CoAl}$ $\left(\mathrm{DS}^{-}\right)-\mathrm{LDH}$, with an interlayer distance of $2.58 \mathrm{~nm}$, will facilitate more electrolyte ions into the inner space of $\mathrm{LDH}$, which leads to a higher electrochemical activity because of the pseudocapacitance originating from a fast and reversible Faradaic reaction between electrolyte and active electrode material. Thus, it is believed that the 
supercapacitor performance of LDH could be markedly enhanced by increasing its layer distance from the insertion of some long chain molecules.

\section{CONCLUSIONS}

In summary, we have synthesized CoAl-LDHs with different interlayer distances by intercalation of different anion ions under hydrothermal conditions. The CoAl (DS $\left.{ }^{-}\right)$-LDHs with an interlayer distance of $2.58 \mathrm{~nm}$ exhibits a much higher specific capacitance of $1481.7 \mathrm{~F} \mathrm{~g}^{-1}$ than the of $\mathrm{CoAl}\left(\mathrm{CO}_{3}^{2-}\right)-\mathrm{LDH}(0.76 \mathrm{~nm})$ and $\mathrm{CoAl}\left(\mathrm{SO}_{4}^{2-}\right)$ $-\mathrm{LDH}(0.87 \mathrm{~nm})$ at a discharge current density of $1 \mathrm{~A} \mathrm{~g}^{-1}$. An ASC based on this $\mathrm{CoAl}\left(\mathrm{DS}^{-}\right)-\mathrm{LDH}$ also shows a better electrochemical performance, including high energy density, power density, and cycling stability. This work shows that larger interlayer spacing, allowing more electrolyte ions to be stored, results in a higher electrochemical activity. These results indicate that our strategy could be expanded to further prepare the other LDHs with different interlayer distance for enhancing its pseudocapacitive performance.

Received 21 August 2017; accepted 9 October 2017;

published online 30 November 2017

1 Simon P, Gogotsi Y. Materials for electrochemical capacitors. Nat Mater, 2008, 7: 845-854

2 Lv W, Li Z, Deng Y, et al. Graphene-based materials for electrochemical energy storage devices: opportunities and challenges. Energ Storage Mater, 2016, 2: 107-138

3 Zhou C, Zhang Y, Li Y, et al. Construction of high-capacitance 3D CoO@polypyrrole nanowire array electrode for aqueous asymmetric supercapacitor. Nano Lett, 2013, 13: 2078-2085

4 Li X, Chen Y, Huang H, et al. Electrospun carbon-based nanostructured electrodes for advanced energy storage-a review. Energ Storage Mater, 2016, 5: 58-92

5 Liang J, Li F, Cheng HM. Carbons: multi-functional energy storage materials. Energ Storage Mater, 2016, 2: A1-A2

6 Xiao Y, Liu S, Li F, et al. 3D hierarchical $\mathrm{Co}_{3} \mathrm{O}_{4}$ twin-spheres with an urchin-like structure: large-scale synthesis, multistep-splitting growth, and electrochemical pseudocapacitors. Adv Funct Mater, 2012, 22: 4052-4059

7 Brezesinski T, Wang J, Tolbert SH, et al. Ordered mesoporous $\alpha$ $\mathrm{MoO}_{3}$ with iso-oriented nanocrystalline walls for thin-film pseudocapacitors. Nat Mater, 2010, 9: 146-151

8 Shi Y, Guo B, Corr SA, et al. Ordered mesoporous metallic $\mathrm{MoO}_{2}$ materials with highly reversible lithium storage capacity. Nano Lett, 2009, 9: 4215-4220

9 Xie L, Hu Z, Lv C, et al. $\mathrm{Co}_{x} \mathrm{Ni}_{1-x}$ double hydroxide nanoparticles with ultrahigh specific capacitances as supercapacitor electrode materials. Electrochim Acta, 2012, 78: 205-211

10 Liu XM, Zhang YH, Zhang XG, et al. Studies on Me/Al-layered double hydroxides $(\mathrm{Me}=\mathrm{Ni}$ and $\mathrm{Co})$ as electrode materials for electrochemical capacitors. Electrochim Acta, 2004, 49: 3137-3141

11 Liang Y, Yoo HD, Li Y, et al. Interlayer-expanded molybdenum disulfide nanocomposites for electrochemical magnesium storage.
Nano Lett, 2015, 15: 2194-2202

12 Lu Z, Zhu W, Lei X, et al. High pseudocapacitive cobalt carbonate hydroxide films derived from CoAl layered double hydroxides. Nanoscale, 2012, 4: 3640-3643

13 Wang B, Williams GR, Chang Z, et al. Hierarchical NiAl layered double hydroxide/multiwalled carbon nanotube/nickel foam electrodes with excellent pseudocapacitive properties. ACS Appl Mater Interfaces, 2014, 6: 16304-16311

14 Zhao J, Chen J, Xu S, et al. Hierarchical NiMn layered double hydroxide/carbon nanotubes architecture with superb energy density for flexible supercapacitors. Adv Funct Mater, 2014, 24: 2938-2946

15 Chen $\mathrm{H}, \mathrm{Hu} \mathrm{L}$, Chen M, et al. Nickel-cobalt layered double hydroxide nanosheets for high-performance supercapacitor electrode materials. Adv Funct Mater, 2014, 24: 934-942

16 Cheng $\mathrm{Y}$, Zhang $\mathrm{H}$, Varanasi $\mathrm{CV}$, et al. Improving the performance of cobalt-nickel hydroxide-based self-supporting electrodes for supercapacitors using accumulative approaches. Energ Environ Sci, 2013, 6: 3314-3321

17 Cao Y, Xiao Y, Gong Y, et al. One-pot synthesis of $\mathrm{MnOOH}$ nanorods on graphene for asymmetric supercapacitors. Electrochim Acta, 2014, 127: 200-207

18 Xiao Y, Cao Y, Gong Y, et al. Electrolyte and composition effects on the performances of asymmetric supercapacitors constructed with $\mathrm{Mn}_{3} \mathrm{O}_{4}$ nanoparticles-graphene nanocomposites. J Power Sources, 2014, 246: 926-933

19 Chen Y, Pang WK, Bai H, et al. Enhanced structural stability of nickel-cobalt hydroxide via intrinsic pillar effect of metaborate for high-power and long-life supercapacitor electrodes. Nano Lett, 2017, 17: 429-436

20 Tang Z, Tang C, Gong H. A high energy density asymmetric supercapacitor from nano-architectured $\mathrm{Ni}(\mathrm{OH})_{2} /$ carbon nanotube electrodes. Adv Funct Mater, 2012, 22: 1272-1278

21 Ogawa M, Hiramine M. Direct correlation between nanostructure and particle morphology during intercalation. Cryst Growth Des, 2014, 14: 1516-1519

22 Zhao H, Nagy KL. Dodecyl sulfate-hydrotalcite nanocomposites for trapping chlorinated organic pollutants in water. J Colloid Interface Sci, 2004, 274: 613-624

23 Kloprogge JT, Wharton D, Hickey L, et al. Infrared and Raman study of interlayer anions $\mathrm{CO}_{3}^{2-}, \mathrm{NO}_{3}^{-}, \mathrm{SO}_{4}^{2-}$ and $\mathrm{ClO}_{4}^{-}$in $\mathrm{Mg} / \mathrm{Al}-$ hydrotalcite. Am Miner, 2002, 87: 623-629

24 Jiang Y, Chen D, Song J, et al. A facile hydrothermal synthesis of graphene porous $\mathrm{NiO}$ nanocomposite and its application in electrochemical capacitors. Electrochim Acta, 2013, 91: 173-178

25 Liu X, Wang C, Dou Y, et al. A NiAl layered double hydroxide@carbon nanoparticles hybrid electrode for high-performance asymmetric supercapacitors. J Mater Chem A, 2014, 2: 1682-1685

26 Xiao Y, Su D, Wang X, et al. Ultrahigh energy density and stable supercapacitor with 2D NiCoAl Layered double hydroxide. Electrochim Acta, 2017, 253: 324-332

27 Wang G, Zhang L, Zhang J. A review of electrode materials for electrochemical supercapacitors. Chem Soc Rev, 2012, 41: 797-828

28 Prasanna SV, Kamath PV. Anion-exchange reactions of layered double hydroxides: interplay between Coulombic and H-bonding interactions. Ind Eng Chem Res, 2009, 48: 6315-6320

29 Yu G, Hu L, Liu N, et al. Enhancing the supercapacitor performance of graphene $/ \mathrm{MnO}_{2}$ nanostructured electrodes by conductive wrapping. Nano Lett, 2011, 11: 4438-4442

30 Abellán G, Coronado E, Martí-Gastaldo C, et al. Hexagonal na- 
nosheets from the exfoliation of $\mathrm{Ni}^{2+}-\mathrm{Fe}^{3+}$ LDHs: a route towards layered multifunctional materials. J Mater Chem, 2010, 20: 74517455

31 Peng W, Li H, Song S. Synthesis of fluorinated graphene/CoAllayered double hydroxide composites as electrode materials for supercapacitors. ACS Appl Mater Interfaces, 2017, 9: 5204-5212

32 Masikhwa TM, Madito MJ, Momodu DY, et al. High performance asymmetric supercapacitor based on CoAl-LDH/GF and activated carbon from expanded graphite. RSC Adv, 2016, 6: 46723-46732

33 Hall PJ, Mirzaeian M, Fletcher SI, et al. Energy storage in electrochemical capacitors: designing functional materials to improve performance. Energ Environ Sci, 2010, 3: 1238-1251

34 Luan F, Wang G, Ling Y, et al. High energy density asymmetric supercapacitors with a nickel oxide nanoflake cathode and a 3D reduced graphene oxide anode. Nanoscale, 2013, 5: 7984-7990

35 Huang $\mathrm{M}$, Zhang $\mathrm{Y}$, Li F, et al. Facile synthesis of hierarchical $\mathrm{Co}_{3} \mathrm{O}_{4} @ \mathrm{MnO}_{2}$ core-shell arrays on $\mathrm{Ni}$ foam for asymmetric supercapacitors. J Power Sources, 2014, 252: 98-106

36 Dubal DP, Gund GS, Lokhande CD, et al. Controlled growth of $\operatorname{CoS}_{x}$ nanostrip arrays $\left(\operatorname{CoS}_{x}\right.$-NSA) on nickel foam for asymmetric supercapacitors. Energ Tech, 2014, 2: 401-408

37 Salunkhe RR, Lin J, Malgras V, et al. Large-scale synthesis of coaxial carbon nanotube/ $\mathrm{Ni}(\mathrm{OH})_{2}$ composites for asymmetric supercapacitor application. Nano Energ, 2015, 11: 211-218

38 Li M, Cheng JP, Wang J, et al. The growth of nickel-manganese and cobalt-manganese layered double hydroxides on reduced graphene oxide for supercapacitor. Electrochim Acta, 2016, 206: 108-115

39 Yu L, Shi N, Liu Q, et al. Facile synthesis of exfoliated Co-Al $\mathrm{LDH}-$ carbon nanotube composites with high performance as supercapacitor electrodes. Phys Chem Chem Phys, 2014, 16: 1793617942

40 Zhang L, Yao H, Li Z, et al. Synthesis of delaminated layered double hydroxides and their assembly with graphene oxide for supercapacitor application. J Alloys Compd, 2017, 711: 31-41

41 Wang X, Sumboja A, Lin M, et al. Enhancing electrochemical reaction sites in nickel-cobalt layered double hydroxides on zinc tin oxide nanowires: a hybrid material for an asymmetric supercapacitor device. Nanoscale, 2012, 4: 7266-7272

42 Yang S, Cheng K, Ye K, et al. A novel asymmetric supercapacitor with buds-like $\mathrm{Co}(\mathrm{OH})_{2}$ used as cathode materials and activated carbon as anode materials. J Electroanal Chem, 2015, 741: 93-99

Acknowledgements This work was financially supported by the National Natural Science Foundation of China (21501152, 21571159, 21671178, 21441003, 51521091 and 51525206), China Postdoctoral Science Foundation (2017M611282), Program for Changjiang Scholars and Innovative Research Team in University (IRT15R61), Ministry of Science and Technology of China (2016YFA0200100 and 2016YBF0100100), Foundation of Zhengzhou University of Light Industry (2014BSJJ054), Strategic Priority Research Program of the Chinese Academy of Sciences (XDA09010104), Projects for Public Entrepreneurship and Public Innovation of ZZULI (2017ZCKJ215) and Key Program of Henan Province for Science and Technology (162102210212).

Author contributions $\mathrm{Xiao} \mathrm{Y}$ and Li F conceived and designed the experiments and wrote the article; Xiao Y, Su D, Wang X performed the experiments. All authors contributed to the general discussion.

Conflict of interest The authors declare that they have no conflict of interest.

Supplementary information Supplementary information is available in the online version of the paper, including part of XPS and BET curve of synthetic materials. 

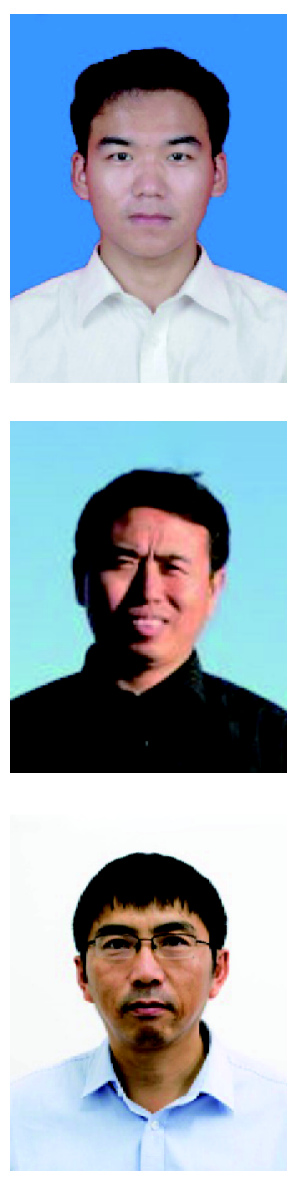

Yuanhua Xiao received his PhD degree in physic chemistry at Xinjiang University in 2014. He is currently a postdoctoral fellow in the group of Prof. Hui-Ming Cheng and Feng Li at the Institute of Metal Research, Chinese Academy of Sciences (IMR, CAS). His main research interests focus on controlled synthesis of novel functional materials with graphene, transition-metal oxide and chalcogenides for chemical sensor, catalysis and energy storage device.
Shaoming Fang is the vice-president of Zhengzhou University of Light Industry. He received his BSc degree (1983) in materials science from Beihang University, MSc degree (1988) and PhD degree (2005) in materials science and engineering from Hebei University of Technology. He is currently the director of the Key Laboratory of Surface and Interface Science and Technology, and the leader of Changjiang Scholars and Innovative Research Team. His current fields of interests are functional materials for energy, sensors and environment application.

Feng $\mathbf{L i}$ is a professor of IMR, CAS. He received his PhD degree in materials science at IMR, CAS in 2001 supervised by Prof. Hui-Ming Cheng. He mainly works on the nano materials for clean energy such as electrode materials for lithium ion battery and supercapacitor. He has published 200 papers peer-reviewed papers such as Angew Chemie, Energy \& Environmental Science, Adv. Mater., Adv. Funct. Mater., ACS Nano, with more 20,000 citations and H-index 60. He is in editor board of New Carbon Materials and Energy Material Storage.

\section{层状双着基复合金属氧化物层间距调控及其电容器性能研究}

肖元化 ${ }^{1}$, 苏当成 ${ }^{1}$, 王雪兆 ${ }^{1}$, 吴诗德 ${ }^{1}$, 周立明 ${ }^{1}$, 方少明 ${ }^{{ }^{*}}$, 李峰 ${ }^{*}$

摘要 在电化学储能过程中, 层状结构材料中较窄的层间距一般会抑制电解液离子的嵌入, 进而限制其层间内部结构在电化学储能过程 中的充分利用. 本文分别选用 3 种不同尺寸的阴离子 $\left(\mathrm{CO}_{3}^{2-}, \mathrm{SO}_{4}^{2-}, \mathrm{DS}^{-}\right.$(十二烷基硫酸根)), 通过简单的一步水热过程, 成功对 $\mathrm{CoAl}-\mathrm{LDH}$ (层状双着基复合金属氧化物)进行插层, 获得了 3 种具有不同层间距的复合材料: $\mathrm{CoAl}\left(\mathrm{CO}_{3}^{2-}\right)-\mathrm{LDH}(0.76 \mathrm{~nm}), \mathrm{CoAl}\left(\mathrm{SO}_{4}^{2-}\right)-\mathrm{LDH}(0.87 \mathrm{~nm})$, $\mathrm{CoAl}\left(\mathrm{DS}^{-}\right)-\mathrm{LDHs}\left(2.58 \mathrm{~nm}\right.$ ). 超级电容器性能研究表明, 在 $1 \mathrm{~A} \mathrm{~g}^{-1}$ 充放电电流密度下, 3 种材料单电极比电容表现出与其层间距大小的一致 性, 即 $\mathrm{CoAl}\left(\mathrm{DS}^{-}\right)-\mathrm{LDHs}\left(1481.7 \mathrm{~F} \mathrm{~g}^{-1}\right)>\mathrm{CoAl}\left(\mathrm{SO}_{4}^{2-}\right)-\mathrm{LDH}\left(1252.7 \mathrm{~F} \mathrm{~g}^{-1}\right)>\mathrm{CoAl}\left(\mathrm{CO}_{3}^{2-}\right)-\mathrm{LDH}\left(1149.2 \mathrm{~F} \mathrm{~g}^{-1}\right)$. 此外, 将 3 种材料与活性炭 $(\mathrm{AC})$ 组

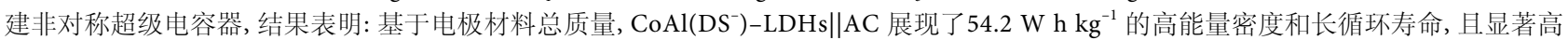
于 $\mathrm{CoAl}\left(\mathrm{SO}_{4}^{2-}\right)-\mathrm{LDH}|| \mathrm{AC}$ 和 $\mathrm{CoAl}\left(\mathrm{CO}_{3}^{2-}\right)-\mathrm{LDH} \| \mathrm{AC}$ 非对称电容器. 该方法为寻找新型高性能超级电容器用层状结构材料提供了新的途径. 